\title{
Pemetaan Masalah dan Solusi Konflik Lokal dalam Pilkada Langsung di Indonesia
}

\author{
MAHI M. HKIKMAT \\ Fakultas Adab dan Humaniora, UIN Sunan Gunung Djati Bandung, Jln. A.H. Nasution 105 Bandung \\ email: mmhikmat@yahoo.co.id
}

\begin{abstract}
Direct elections in Indonesian was born after the reform. The change of Law 22/1999 becomes Law 32/2004 has changed the Regional Head of the Parliament election becomes elected by all the people of the region. However, direct election is not free from problems. To discover this fact, it is conducted research on Problem Mapping and Local conflict Solutions in Direct elections in Indonesia. By using descriptive qualitative method, it is concluded that: The main problem is the Direct Election of the general policy of the Government in the form of "rules of play" and the adequacy of the implementation time to implement it. It has spawned some weaknesses, such as: (a) List of Voters is not clear; (b) Inadequate Facilities-Infrastructure \& Monitoring; (c) Delivery of Ballot are late; (d) the candidate's Psychology \& Supporters are not ready; (e) the socialization is not maximum; and (f) Election Commission is not experienced.
\end{abstract}

Keywords: direct election, people, conflicts, region

Abstrak. Pemilihan Langsung di Indonesia lahir pascareformasi. Perubahan UU No. 22/1999 menjadi UU No. 32/2004 telah mengubah Pilkada semula dipilih DPRD menjadi oleh seluruh rakyat daerah. Namun, Pilkada langsung tidak lepas dari masalah. Untuk mengungkap fakta tersebut, dilakukan kajian Pemetaan Masalah dan Solusi Konflik Lokal dalam Pilkada Langsung di Indonesia. Dengan metode deskriptif kualitatif, didapat kesimpulan: Masalah utama Pilkada, ketidakmatangan kebijakan umum Pemerintah dalam bentuk "aturan main" dan kecukupan waktu implementasi. Hal itu melahirkan sederet kelemahan: (a) Daftar Pemilih Belum Jelas; (b) Sarana-Prasarana dan Pengawasan Tidak memadai; (c) Pengiriman Surat Suara Terlambat; (d) Psikologi Calon \& Pendukung Tidak Siap; (e) Sosialisasi Tidak Maksimal; dan (f) KPU Belum Berpengalaman.

Kata Kunci : pilkada langsung, rakyat, konflik, daerah

\section{Pendahuluan}

Dalam konteks penyelenggaraan negara yang demokratis, pelaksanaan Pemilihan Kepala Daerah (Pilkada) secara langsung di Indonesia adalah pengalaman yang sangat berharga. Selama puluhan tahun Indonesia berdiri sebagai negara merdeka, baru pada tahun 2005-lah rakyat memiliki kesempatan untuk ikut andil dalam menentukan pimpinan pemerintahan di daerah.

Realitas itu telah menyirnakan berbagai keyakinan masa lalu dan menjawab alasan-alasan dulu bahwa pemilu langsung tidak mungkin karena wilayah terlalu luas, rakyat terlalu banyak, dan dana yang terbatas. Pada era ini telah merebak semangat langsung dalam memilih pimpinan, baik di tingkat pusat maupun daerah. Kendati secara historis, pemilihan langsung dalam menentukan pemimpin bukan hal baru. Banyak masyarakat Indonesia yang sudah terbiasa memilih kepala desa secara langsung. Namun, dalam wilayah yang lebih luas dan jum1ah penduduk yang lebih banyak, pada era inilah zamannya dan rakyat Indonesia telah memulainya. Pembaruan di bidang politik dan pemerintahan yang dibawa arus reformasi, menurut Iskandar (dalam Jurnal MIMBAR, 2003: 02), menyentuh persoalan yang paling mendasar, yakni "demokratisasi."

Bercermin dari keberhasilan pemilihan presiden langsung, rakyat Indonesia pun dituntut untuk melangkah pada pemilihan-pemilihan langsung lainnya di daerah. Sebagaimana isi UU No.32 tahun 2004 sebagai revisi dari UU No. 22 tahun 1999 bahwa seluruh kepala daerah provinsi dan kota/kabupaten harus dipilih secara langsung.

Dalam kadar kuantitas, Pilkada langsung diserahkan pada pemilih (rakyat). Hanya calon yang mendapatkan suara rakyat terbanyaklah yang akan duduk di singgasana daerah. Realitas itu 
menekankan, memang rakyatlah yang berkuasa. Tanpa dukungan rakyat, siapa pun jangan berharap menjadi gubernur, bupati, atau walikota.

Dalam realitas kesertaan seluruh rakyat Indonesia yang berusia di atas 17 tahun, atau sudah menikah, yang jumlahnya sangat besar, dogma lama yang dianggap kendala tidak mungkin, tetap saja menyuratkan persoalan. Persoalan yang akan mengurangi kekhidmatan pesta demokrasi daerah, menurut Koordinator Kaukus Daerah Konflik \& Pascakonflik M. Ichsan Loulembah (2005), yakni anggaran yang tidak sedikit, kemungkinan mark-up biaya Pilkada, persiapan yang kurang memadai, pengalaman memilih pemimpin yang belum mapan, stabilitas keamanan yang masih rapuh, dan kesiapan menerima hasil Pilkada yang belum matang.

Kesertaan seluruh rakyat secara langsung pun, selain dapat menguatkan legitimasi politik kepala daerah, tidak terlepas pula dari berbagai potensi yang dapat mengaburkan substansi Pilkada langsung. Bahkan, bukan tidak mungkin, justru substansi tujuan Pilkada untuk menyejahterakan rakyat berbalik menjadi membangkrutkan negara dan memiskinkan rakyat.

Padahal, dalam pandangan Hikmat (2010: 169-170), Pilkada langsung dapat memberikan pembelajaran politik dalam tiga aspek, yakni: meningkatkan kesadaran politik masyarakat lokal; mengorganisasi masyarakat ke dalam aktivitas politik yang memberi peluang lebih besar pada setiap orang untuk berpartisipasi; dan memperluas akses masyarakat lokal untuk memengaruhi proses pengambilan keputusan yang menyangkut kepentingan mereka.

Kesertaan seluruh rakyat dalam Pilkada langsung pun, membangkitkan potensi-potensi lokal, termasuk potensi kelompok-kelompok masyarakat lokal yang tergabung dalam berbagai organisasi daerah. Dalam konteks ini, mereka sangat berperan dalam menajamkan mata tombak pendekatan terhadap pemilih. Dengan perbedaan dalam mengusung kandidat calon kepala daerah, gesekan di antara kelompok masyarakat lokal tersebut sangat memungkinkan terjadi. Bahkan, gesekan tersebut dapat saja meletus menjadi konflik-konflik lokal. Konflik ini lebih membahayakan karena di antara masyarakat pendukung berhadapan langsung dengan komando elit-elit dan aktor-aktor politik lokal.

Kendati dalam pandangan Nurlimah (dalam Jurnal MIMBAR, 2011:02), fenomena konflik dalam dinamika kehidupan masyarakat maupun sistem politik Indonesia telah menjadi faktor penting. Karenanya, konflik tidaklah menjadi permasalahan yang rumit apabila berproses secara alami. Namun, yang menjadi keprihatinan adalah turut aktifnya pers dalam memicu muncul dan meluasnya konflik yang dikonstruksikan melalui pemberitaan bernada provokatif.
Beranjak dari kontras dua fenomena, di antara aspek positif dan dampak negatif itulah, sehingga kajian tentang Pilkada masih dibutuhkan. Maksud dilaksanakannya kajian adalah untuk memetakan pelaksanaan kegiatan Pilkada secara langsung di Indonesia tahun 2013, sekaligus menyerap permasalahan yang muncul dan mencari solusi yang tepat agar Pilkada langsung ke depan dapat diperbaiki.

Adapun tujuan kajian ini untukmengidentifikasi masalah yang muncul pada tahapan pelaksanaan Pilkada serta mengidentifikasi tindakan pencegahan yang dapat dan harus dilakukan untuk mengatasi masalah-masalah yang dapat memicu konflik horizontal, bahkan menggagalkan pelaksanaan Pilkada.

Kajian ini akan difokuskan pada pelaksanaan Pilkada secara langsung di Indonesia dengan objek penelitian Peristiwa Pilkada Langsung di Indonesia selama tahun 2013 studi kasus pada Pilkada langsung beberapa daerah yang berkonflik, yakni Pilgub Jabar, Pilbup Cirebon, dan Pilwalkot Depok, Pilgub Sumsel, Pilgub Bali, Pilbup Sumba Barat Daya, dan Pilgub Maluku. Data peristiwa Pilkada Langsung pada daerah penelitian diambil melalui observasi, baik ke lapangan maupun melalui pemberitaan di media massa: televisi, surat kabar, dan internet.

Dari potret peristiwa Pilkada di kawasan kajian didapat permasalahan pokok sebagai berikut :

Pertama, pelaksanaan Pilkada Langsung di Indonesia adalah implementasi dari demokrasi langsung yang diidamkan-idamkan oleh seluruh rakyat, sehingga memungkinkan semua pihak, baik penyelenggara maupun peserta antusias melaksanakan.

Kedua, sejak dulu Pilkada selalu dikaitkan dengan uang, sehingga isu money politics atau gizi dalam kegiatan tersebut menjadi bagian yang riskan. Tindak money politics dalam pelaksanaan Pilkada secara langsung sangat memungkin terjadi, bahkan lebih besar dari masa-masa pemilihan sebelumnya.

Ketiga, hampir semua Pilkada secara langsung di Indonesia memicu terjadinya konflik di antara warga, terutama di antara warga yang memiliki pilihan yang berbeda. Hal ini pun merupakan fenomena belum dewasanya pendidikan politik rakyat. Konflik tersebut di antaranya dipicu oleh: ketidakpuasan yang kalah, perbedaan persepsi nilai hasil pemilihan karena berbeda cara menghitung, kecurigaan adanya kecurangan, dan sebagainya.

Dalam kajian ini digunakan pendekatan kebijakan yang relevan melalui studi dokumen kebijakan. Kebijakan yang dijadikan pijakan adalah UUD 1945, UU No. 22 Tahun 1999 dan UU No. 32 Tahun 2004 tentang Pemerintah Daerah, UU No. 12 Tahun 2012, serta Peraturan Pemerintah No. 6 Tahun 2005 tentang Pemilihan Kepala Daerah.

Selain pemahaman terhadap peraturan perundang-undangan yang berlaku, diperlukan juga 
pemahaman terhadap kebijakan KPU(D), baik yang berlaku ekstern maupun intern serta nilai-nilai yang berlaku di masyarakat daerah pemilihan. Nilai-nilai di masyarakat ini sangat penting karena tidak jarang konflik terjadi karena terdapatnya perbedaan frame di antara kebijakan pemerintah dengan nilai-nilai yang tidak tertulis di masyarakat.

Kajian ini dilakukan secara sistematis dengan menggunakan metode kajian deskriptif kualitatif. Pendekatan untuk mengumpulkan dan menganalisis data dalam kajian ini adalah memadukan data kuantitatif dengan analisis kualitatif. Selain dari peristiwa Pilkada langsung pada wilayah kajian, data didapat baik hasil observasi langsung maupun melalui pemberitaan di media massa, serta hasil studi dokumentasi dari penyelenggara Pemilu.

\section{Pembahasan}

Dalam konteks penyelenggaraan negara yang demokratis, pelaksanaan Pilkada secara langsung di Indonesia adalah pengalaman yang sangat berharga. Selama puluhan tahun Indonesia berdiri menjadi negara merdeka, baru pada tahun 2005-lah rakyat memiliki kesempatan untuk ikut andil dalam menentukan pimpinan pemerintahan di daerah.

Dalam pandangan ahli pikir Prancis, Jean Jacques Rousseau (1986), pemilihan pemimpin pemerintahan secara langsung oleh seluruh rakyat adalah bukti telah tercapainya kehidupan demokrasi yang paling tinggi dalam suatu negara. Ia berpandangan, hubungan rakyat dengan negaranya haruslah langsung, tidak di antarai oleh badan apa pun. Sistem perwakilan dicap oleh Rousseau sebagai sistem yang terbit dari kemalasan orang untuk menaruh perhatian terhadap masalah bersama dan juga dari nafsu akan uang. Bukankah wakil rakyat itu dibayar? Oleh sebab itu, penyertaan rakyat dalam pemerintahan haruslah langsung, tidak diwakilkan dan ini merupakan bakti yang sewajarnya dari manusia merdeka, manusia yang berupa tuan.

Kendati pemikiran Rousseau tersebut tidak dapat diadopsi secara mutlak dalam realitas pemerintahan Indonesia, setidaknya pelaksanaan pemilihan langsung para kepala daerah merupakan bukti bahwa demokrasi yang benar itu yang betulbetul mengakomodasi aspirasi rakyat. Hal itu makin kentara dalam teori terbentuknya negara dari Thomas Hobbes (dalam Susilo, 1998) bahwa negara itu terbentuk karena adanya pernjanjian di antara rakyat (masyarakat) dalam bentuk contract social. Konsep ini dapat dimaknai bahwa rakyatlah yang paling memiliki kekuasaan pada negara dan pemerintahan.

Pemikiran-pemikiran politik seperti itu menggeliat pada era reformasi. Dominasi kekuasaan yang terjadi pada masa Orde Baru telah melahirkan perlawanan yang dahsyat dalam berbagai aspek kehidupan. Bahkan, perlawanan terhadap rezim Orde Baru itu telah melahirkan era baru, yang disebut era reformasi.

Reformasi politik pun terjadi pada Pemerintahan Daerah. UU Pemerintah Daerah No. 5 Tahun 1974 yang menekankan sentralistik kekuasan pada pemerintah pusat sertamerta diubah dengan UU No. 22 Tahun 1999 tentang Pemerintah Daerah yang lebih dikenal dengan UU Otonomi Daerah karena di dalamnya banyak mengatur tentang pembagian kekuasaan antara pemerintah pusat dan pemerintah daerah. Tidak berhenti hanya di situ, geliat otonomi daerah pun terus bergulir dan sangat cepat. UU No. 22 Tahun 1999 pun tidak dapat bertahan lama digantikan dengan UU No. 32 Tahun 2004 tentang Pemerintahan Daerah.

Hal paling esensial dari pergantian UU Pemerintahan Daerah adalah dalam penentuan kepala daerah. Pada UU No. 5/1974, pengangkatan kepala daerah menjadi wewenang penuh Pemerintah Pusat, UU No. 22/1999 akses DPRD dibuka lebar dengan ikut menentukan kepala daerah melalui pemilihan, dan UU No. 32/2004 menyuratkan Pemilihan Kepala Daerah secara Langsung oleh seluruh rakyat daerah.

UU No. 32/2004 yang secara teknis diatur dalam Peraturan Pemerintah No. 6 Tahun 2005, berdasarkan hasil penelitian Hikmat (2006), telah membuktikan bahwa Pilkada di Republik ini dapat diselenggarakan langsung melibatkan seluruh rakyat daerah. Pada tahun pertama pelaksanaan (2005), sebanyak 92 persen pelaksanaan Pilkada langsung berjalan baik dan lancar; hanya 8 persen yang bermasalah.

Pelaksanaan Pilkada secara langsung itu diawali dengan Pilkada di Kabupaten Kutai Kertanegara, Kalimantan Timur. Meski terjadi riak-riak kecil, akhirya kabupaten ini memiliki bupati yang definitif. Daftar panjang Pilkada 2005 ditutup dengan pemilihan Bupati di Kabupaten Tapanuli Tengah, 11 Desember 2005. Namun, akibat keputusan Departemen Dalam Negeri yang meminta penundaan Pilkada, hingga memasuki 2006, kabupaten itu belum memiliki bupati. Depdagri juga harus menyelesaikan Pilkada di Kota Depok (2005), Kabupaten Mappi Papua (2005), serta Pilkada Provinsi Papua dan Irian Jaya Barat (2006).

Selain masih menyisakan masalah, tahun berikutnya pun Pilkada secara langsung di 86 daerah, yakni 79 kabupaten/kota dan tujuh provinsi, dibuka dengan lembaran kelam Pilkada Tuban, 26 April 2006. Pilkada di Tuban merupakan bukti bahwa pengalaman tidak menjadi pelajaran bagi sebagian rakyat Tuban untuk menerima kekalahan dengan tangan terbuka. Kekalahan pasangan calon kepala daerah tidak disikapi dengan kearifan, tetapi ditanggapi dengan kemarahan, sehingga terjadilah pengrusakan berbagai sarana, baik sarana pemerintah maupun sarana umum dan sarana pribadi milik calon terpilih.

Realitas konflik Pilkada di Tuban yang 
berlanjut pada tindak kekerasan massa, tentu bukan hanya menjadi bahan evaluasi besar bagi warga Tuban, tetapi juga harus menjadi cerminan bagi seluruh rakyat Indonesia, termasuk pemerintah dan para penyelenggara Pilkada. Anggapan kesuksesan pelaksanaan Pilkada langsung tahun 2007 harus dibongkar lagi, sehingga dapat ditemukan permasalahan-permasalahan rumit yang cenderung dapat berulang dalam Pilkada langsung di daerah lainnya.

Pemilihan kepala daerah oleh DPRD saja pada masa berlakunya UU No. 22/1999, menurut hasil penelitian Hikmat (dalam Tesis, 2005), ternyata masih menyisakan masalah. Hal itu terjadi salah satunya di Propinsi Lampung. Permasalahan pelik yang melingkupi pemilihan Gubernur dan Wakil Gubernur Lampung (2005), ternyata hingga UU No.22/1999 diganti oleh UU No. 32/2004, masih belum tuntas. Bahkan, pada era Pilkada Langsung, permasalahan tersebut menjadi lebih rumit dan sempat menjadi bagian penghalang penyelenggaraan Pilkada Langsung, khususnya dalam rencana pemilihan Gubernur dan Wakil Gubernur Lampung.

Internasional Crisis Group (ICG) tahun 2010 mencatat sekitar 10 persen dari 200 Pilkada yang digelar sepanjang tahun 2010 diwarnai aksi kekerasan, seperti di Mojokerto, Jawa Timur, Tana Toraja di Sulawesi Selatan dan Toli-toli di Sulawesi Tengah. ICG menyebutkan, kekerasan dalam Pilkada, antara lain, dipicu oleh lemahnya posisi penyelenggara Pemilu, seperti KPU kabupaten/kota dan Panwaslu (diunduh dari http://pilkadaponorogo. com, 2 Juni 2014)

Kendati sudah berjalan lebih kurang delapan tahun, problem penyelenggaraan Pilkada tetap saja terjadi. Tahun 2013, pemilihan gubernur Bali, 15 Mei 2013 berujung pada gugatan ke MK (Mahkamah Konstitusi) yang dilakukan oleh PDI Perjuangan. Pasangan calon Aan Puspayoga-Dewa Sukrawan menggugat hasil Pilgub Bali 2013 ke MK atas hasil rekapitulasi suara KPU yang dianggap tidak akurat. Bahkan, sejumlah anggota Forum Masyarakat Peduli dan Cinta Bali melaporkan mantan Ketua MK, Akil Mochtar ke KPK atas dugaan tindak pidana korupsi dalam pemeriksaan perkara perselisihan hasil perhitungan suara Pilgub Bali.

Di Jawa Barat, kendati Pilgub Jabar 2008 berjalan aman (Hikmat dalam Disertasi, 2010), tetapi pada Pilgub 2013 sempat bermasalah. Setidaknya, ketidakpuasan pasangan calon Rieke Diah Pitaloka dan Teten Masduki merupakan bukti. Pasangan calon yang didukung PDI Perjuangan itu melaporkan sejumlah kasus yang berindikasi pelanggaran ke MK. Walaupun akhirnya MK menolaknya. MK menyatakan tak menemukan bukti memadai bahwa ada pelanggaran yang bersifat masif, terstruktur, dan sistematis dalam Pilgub Jabar 2013.

Hal yang sama juga terjadi pada Pemilihan
Bupati Cirebon 2013. Pasangan Hj. Raden Sri Heviyana - H. Rakhmat mengadu ke MK. Mereka menyatakan telah terjadi pelanggaran yang bersifat administratif, massif, terstruktur, dan sistematis dalam pelaksanaan Pilbup Cirebon putaran kedua, 29 Desember 2013; di antaranya dalam penentuan waktu penyelenggaraan pemungutan suara oleh KPU Kabupaten Cirebon. Walaupun akhirnya pengaduan itu pun tidak dikabulkan MK.

Begitu juga dalam Pilbup Sumba Barat Daya, Nusa Tenggara Timur 2013. MK menolak gugatan pasangan Konco Ale Ate. Dalam amar putusan, MK menyebutkan, hasil rekapitulasi dalam Pilbup Sumba Barat Daya 2013 yang benar adalah rekapitulasi sebagaimana dituangkan KPU SBD dalam Berita Acara Rekapitulasi Hasil Penghitungan Suara Pilbup Sumba Barat Daya tertanggal 10 Agustus 2013. Putusan MK tersebut memicu bentrokan antarpendukung pasangan calon, sehingga tiga orang meninggal dunia dan 19 rumah penduduk terbakar serta ratusan warga mengungsi ke Waetabula, Ibu Kota Kabupaten Sumba Barat Daya (Diunduh Mei 2014 dari http://www.investor.co.id/ home/tiga-meninggal-konflik-pilkada-di-sumbadaya-barat/67917).

Pemilihan Gubernur Sumatera Selatan 2013 pun diwarnai protes dan pengaduan dari calon kepala daerah, yang menurut hasil hitung cepat beberapa lembaga survei dinyatakan kalah. Keputusan MK juga tetap memenangkan pasangan Romi Herton-Harnojoyo, sehingga disambut aksi kerusuhan pembakaran toko elektronik di Kota Palembang.

Dari Pilkada Maluku, meskipun PTUN Ambon memutuskan penetapan kelima pasangan calon Gubernur dan Wakil Gubernur Maluku tidak sah, KPU Maluku tetap bersikeras melaksanakan jadwal Pilkada Maluku, Selasa, 11 Juni 2013. Hal itu pun menuai masalah pasca Pilgub Maluku. (Diunduh, Mei 2014, http://www.rumahpemilu.org/in/read/1965/ Konflik-di-Banyak-Pilkada).

Dari realitas sejumlah permasalahan dalam Pilkada itulah, sehingga Pilkada langsung sampai saat ini masih mendapat tanggapan "miring" dari beberapa pihak. Mantan Menteri Otonomi Daerah Ryas Rasyid, dalam Ceramah Umum Anggota Dewan Pertimbangan Presiden RI, Kamis 2 Mei 2013, seakan menyodorkan ironi. Menurutnya, Pilkada langsung tidak harus serentak di seluruh daerah, karena tidak otomatis menghasilkan figur kepala daerah yang berkualitas. Bagi daerah-daerah yang dengan potensi keuangan, manajemen daerah, serta tingkat kesejahteraan masyarakat masih rendah, proses Pilkada bisa dikembalikan melalui mekanisme perwakilan di DPRD.

Menurut Ryas, pelaksanaan Pilkada di beberapa daerah sesuai amanat UU No.32/2004 tentang Pemerintah Daerah tidak menjamin keterpilihan figur kepala daerah berkualitas. Di 
beberapa daerah hasil Pilkada langsung malah lebih buruk dibandingkan proses pemilihan sebelumnya. Dalam kondisi masyarakat yang mayoritas berpendidikan rendah, keterpilihan seorang pemimpin lebih dikarenakan faktor popularitas atau karena faktor uang. Bahkan, ia memperkirakan, Pilkada langsung di berbagai wilayah akan terus berlangsung amburadul.

\section{Munculnya Masalah Pilkada}

Berdasarkan hasil kajian, baik terhadap dokumen hasil penelitian Pilkada sebelumnya, observasi langsung pada peristiwa Pilkada 2013 maupun kajian pada dokumen media massa, penyelenggara Pemilu, dan peraturan perundangundangan, pelaksanaan Pilkada secara langsung di Indonesia sangat memungkinkan memunculkan masalah. Hal itu berkait dengan kesiapan semua stakeholder yang terlibat dalam Pilkada Langsung masih sangat rendah dan jangka waktu yang terlalu sempit. Daftar pemilih tetap yang belum jelas jumlahnya karena waktu pendataan sangat singkat, sehingga pemutakhiran tidak optimal. Apalagi, jika Pilkada secara Langsung dilaksanakan di daerah yang wilayahnya sangat luas dan tidak terdapat alat transportasi memadai, seperti Pilgub Papua dan Irian Jaya Barat. Lambatnya pendataan pemilih memungkinkan banyak warga tidak terdaftar dan sulitnya daerah pemilihan, sehingga banyak warga tidak memilih. Semua itu dapat menjadi masalah yang memicu terjadinya konflik di antara para calon atau para pendukung calon.

Selain itu, keterbatasan waktu pelaksanaan Pilkada Langsung pun mendorong tidak maksimalnya pengawasan dan rekruitmen kandidat calon. Ketidakmaksimalan itu kembali ke permasalahan waktu yang terlalu sempit. Contohnya, ada beberapa daerah yang belum siap memiliki standar anggaran. Standar anggaran masing-masing daerah memang berbeda bergantung pada jumlah pemilih dan luas daerahnya. Ada standar anggaran daerah yang sangat minim, sehingga KPU harus kreatif, misalnya, memerlukan kotak suara 600 buah, karena anggaran minim, KPU harus memangkasnya menjadi 300 buah atau pemungutan suara tidak dengan kotak suara, tetapi dengan kantung-kantung kecil yang rawan manipulasi seperti terjadi di Papua.

Dampak ketidakmatangan kesiapan pelaksanaan Pilkada langsung pun, menurut pakar hukum Indra Prawira dalam Bincang-Bincang Pilkada pada PR FM, 8 Agustus 2013, dilihat dari segi psikologi, para calon dan masyarakat belum siap menerima kekalahan. Oleh karena itu, ketika kandidat kepala daerah yang didukung kalah, mereka emosional, bahkan ada juga yang meluapkan kemarahan melalui tindakan anarkis.

Ketidakmatangan atau ketergesaan pelaksanaan Pilkada langsung rentan terjadinya berbagai masalah. Oleh karena itu, wajar jika banyak pengamat menyimpulkan bahwa semua permasalahan dalam Pilkada langsung adalah buah dari ketidakmatangan rencana pemerintah dalam menyelenggaraan Pilkada di daerah. Hal itu sempat disadari oleh beberapa pemerintah daerah, termasuk para penyelenggara Pilkada di daerah.

Pakar Tata Negara Universitas Padjadjaran, I Gde Pantja Astawa dalam Seminar Keterbukaan Unformasi Pilgub Jabar 2013 di Hotel Katulistiwa Jatinangor, 12 Desember 2013, pun menguatkan bahwa kelemahan Pilkada langsung terletak pada persiapan. Alokasi waktu yang sempit menjadi kendala. Mulai dari persiapan, kemudian seseorang terpilih sampai ia dilantik, waktunya mepet sekali. Tanggung jawab yang utama berada pada pundak KPU daerah. Meskipun KPU daerah memiliki pengalaman pada pemilihan legislatif maupun Pilpres, namun Pilkada Iangsung nuansanya berbeda.

Karakteristik daerah, tingkat kecerdasan, dan tingkat kekritisan masing-masing daerah berbeda satu sama lain. Tidak mudah bagi KPU(D) untuk menyelenggarakan Pilkada secara langsung, terutama dari segi administrasi sampai perhitungan suara. Mengerahkan partisipasi masyarakat juga tidak mudah, dalam artian sosialisasi ke masyarakat dalam tingkat grass root belum maksimal.

Selain itu, Pemerintah melalui Menteri Dalam Negeri pun memperpendek waktu proses Pilkada dari 180 hari menjadi 156 hari. Alasannya efisiensi dan efektivitas serta menghindari konflik di daerah. Padahal pemendekan waktu ini berimbas pada kualitas Pilkada. KPU(D) harus menggelar Pilkada langsung dalam waktu sempit dan terburu-buru.

Menteri Dalam Negeri, Gamawan Fauzi (Diunduh dari https://www.facebook.com/ PRFMNewsChannel, 18 Juni 2014) pun mengakui bahwa sistem Pilkada langsung di daerah, baik di level provinsi maupun kabupaten/kota, sering berujung pada kerusuhan. Menurutnya, lebih 50 orang yang meninggal (akibat pilkada) sejak tahun 2005. Evaluasi yang dilakukan Kemendagri, menunjukkan bahwa masyarakat dan elit partai politik di sejumlah daerah belum matang berpolitik.

Apalagi hasil Pilkada langsung pun banyak yang belum sesuai dengan harapan rakyat. Banyaknya kepala daerah yang tersangkut kasus korupsi menjadi tamparan keras terhadap hasil pelaksanaan Pilkada. Ternyata Pilkada yang dilaksanakan secara langsung oleh rakyat, belum mampu sepenuhnya menghasilkan kepala daerah yang bersih dan bebas dari kasus korupsi.

Padahal, ide awal kelahiran Pilkada langsung yang dimulai tahun 2005 , untuk mencari pemimpin yang punya legitimasi kuat di masyarakat dan berkualitas serta menghindari terjadinya proses politik uang yang selama pemilihan dilakukan DPRD sering terjadi. Pilkada langsung berangkat dari 
harapan agar kepala daerah yang dihasilkan benarbenar mampu membawa perubahan masyarakat lebih sejahtera dari sebelumnya.

Direktur Jenderal Otonomi Daerah Kemendagri Djohermansyah Djohan dalam Konferensi Nasional Hukum Tata Negara di Sawahlunto, 39 Mei 2014, menyebutkan, dari hasil evaluasi, sedikitnya ada tujuh masalah yang mengikuti proses pilkada. Pertama, tingginya biaya penyelenggaraan pilkada, mencapai 0,5-5 persen dari total APBD provinsi, kabupaten dan kota yang menyelenggarakan pilkada.

Kedua, meningkatnya ekskalasi konflik horizontal di tengah masyarakat di daerah. Rendahnya tingkat pendidikan dan kesejahteraan membuat sentimen politik dan primordial mudah berubah menjadi bentrok fisik antarpendukung. Ketiga, maraknya gugatan proses pilkada. Keempat, disharmoni dan rivalitas antara kepala daerah dan wakil kepala daerah meningkat. Faktanya, hanya 50 kepala daerah dan wakil kepala daerah (7 persen) dari 2010 hingga 2013 berpasangan kembali untuk periode kedua.

Kelima, tingginya biaya politik yang harus dikeluarkan peserta pilkada langsung, yakni biaya mahar Parpol, menggerakkan mesin Parpol dan tim sukses, kampanye, saksi di TPS, dan biaya penyelesaian kasus hukum di MK. Kondisi tersebut menjadi faktor determinan yang membuat kepala daerah dan wakil kepala daerah tersandera untuk mengembalikan modal politik. Sepanjang 20042013, sebanyak 319 kepala daerah dan wakil kepala daerah tersangkut dengan masalah hukum, terutama tindak pidana korupsi.

Keenam, Pilkada langsung mengakibatkan maraknya politik uang. Sementara itu, masalah ketujuh, Pilkada yang melahirkan Pilkada putaran kedua dan Pilkada ulang memengaruhi antusiasme dan motivasi pemilih, sehingga tingkat partisipasi pemilih rendah.

\section{Pemetaan Masalah Pilkada}

Berdasar hasil kajian, masalah-masalah yang muncul dalam pelaksanaan Pilkada Langsung yang berkaitan erat dengan kematangan perencanaan, di antaranya:

Pertama, minimnya antusiasme dan partisipasi masyarakat dalam Pilkada langsung. Hal itu terjadi hampir di semua event pelaksanaan Pilkada Langsung. Hal tersebut dapat disebabkan banyak faktor, di antaranya:

Rakyat Indonesia sejak krisis ekonomi mendera lebih berkonsentrasi pada kebutuhan ekonomi akibat harga-harga kebutuhan pokok yang naik dan konsekuensi dari kenaikan harga BBM. Jadi, rakyat lebih memilih memikirkan kebutuhan hidupnya daripada berpikir tentang Pilkada. Hal itu terjadi karena sebagian besar rakyat pemilih belum melihat adanya feedbacklangsung dari Pilkada yang dapat membawa mereka pada kesejahteraan yang lebih baik.

Persepsi rakyat Indonesia terhadap partai politik sudah mulai bergeser. Rakyat menganggap bahwa Parpol memperhatikan mereka hanya saat dibutuhkan untuk kepentingan dukungan suara. Rakyat pun mengaku bahwa mereka sudah jemu dengan janji-janji Parpol yang bercadar membela kepentingan rakyat. Oleh karena itu, mereka memiliki kesimpulan tidak ada gunanya ikut berpartisipasi dalam Pilkada.

Munculnya pemilih yang golput, artinya pemilih tidak menggunakan hak pilihnya dalam berdemokrasi. Kendati dalam pandangan Surbakti (2008) bahwa dalam konteks pemilih yang terdaftar, tetapi tidak memilih terdapat sejumlah kategori, yakni: (1) Pemilih siluman (ghost voters), yaitu mereka yang sudah meninggal atau pindah, tetapi masih terdaftar; (2) Pemilih yang tidak ke TPS karena ada kegiatan lain saat pemilihan; (3) Pemilih yang tidak tahu sudah terdaftar di DPT; (4) Warga tidak memilih karena tidak percaya pada kepada sistem politik dan sistem Pilkada.

Salah satu problem yang urgen dalam Pilkada Langsung, yakni terabaikannya legalitas faktual jumlah peserta pemilihan. Menurut Peraturan Pemerintah No.6 tahun 2005, pengesahan hasil pemilu harus mempertimbangkan persentase jumlah pendaftar pemilih terhadap penduduk usia hak memilih (17 tahun) atau sudah menikah atau jumlah pemilih terhadap pendaftar.

Kedua, faktor yang menjadi sumber masalah adalah administrasi yang lemah. Administrasi Pilkada langsung yang kurang baik rentan terhadap sengketa hasil Pilkada. Sejumlah urusan administratif seperti pendataan atau pemuktahiran data calon pemilih, misalnya, tidak berlangsung sebagaimana mestinya. Sejak 2008 hingga 2013, terdapat 729 sengketa hasil pilkada, belum termasuk gugatan di PTUN dan gugatan SK pengangkatan.

Ketiga, Proses sosialisasi pelaksanaan Pilkada secara langsung yang tidak memadai mengakibatkan banyaknya tuntutan yang timbul pasca Pilkada. Oleh karena itu, sosialisasi Pilkada mesti dijadikan tumpuan utama dalam menyukseskan salah satu bentuk sistem demokrasi. Selain itu, dalam proses sosialisasi juga perlu ditekankan satu cara dalam mendidik masyarakat berpolitik. Tujuannya adalah membangun masyarakat yang kritis (critical voters). Karena Pilkada langsung memberikan kesempatan kepada rakyat untuk memilih kepala daerah secara langsung, maka diharapkan rakyat dapat menggunakan hak pilihnya secara cerdas. Maksudnya, dukungan terhadap calon kepala daerah mesti beranjak dari pertimbangan kritis-rasional atas visi dan program kerjanya.

Keempat, dalam hal institusi pelaksana, Pilkada langsung yang jujur dan adil dapat terwujud 
manakala seluruh institusi yang terkait berada dalam posisi independen dan mandiri. Independen, artinya anggota KPUD berasal dari unsur nonparpol, sedangkan mandiri maksudnya KPUD memilki kewenangan untuk mengontrol birokrasinya sendiri (Sekretariat KPUD tidak berada di bawah birokrasi pemerintahan).

Kelima, hubungan antara KPU-DPRD-KPUD juga tampaknya masih berpotensi menimbulkan konflik, khususnya terkait dengan penafsiran yang berbeda tentang keharusan KPUD bertanggung jawab pada DPRD, dan bukan pada KPU seperti pada Pemilu 2004 lalu. Hal itu perlu ada upaya sosialisasi secara intensif bagi seluruh stakeholders (Pemda, DPRD, KPUD, dan komponen masyarakat) agar ada kesamaan pemahaman mengenai ketentuan ini, sehingga tidak memunculkan masalah di kemudian hari yang dapat melemahkan legitimasi politik pasangan calon yang terpilih.

Sosialisasi ini dapat menjadi media untuk menjelaskan peran dan fungsi masing-masing lembaga terkait, sehingga masyarakat bisa menilai seberapa jauh Pilkada secara langsung mampu menjamin aspirasi publik. Berbagai kekisruhan Pilkada juga tidak terlepas dari aturan Pilkada yang masih dirasakan abstrak atau multi-interpretasi. Dalam jangka pendek cukup peraturan pemerintah yang mengatur teknis Pilkada yang direvisi. Seperti, pengaturan KPUD, sehingga lembaga itu tidak lagi menjadi sasaran tembak berbagai kelompok kepentingan atau bisa juga diatur kembali tata hubungan DPRD dengan KPUD.

Keenam, dalam hal teknis, masih terdapat sejumlah peraturan yang memerlukan penjelasan lebih lanjut, misalnya, menyangkut kriteria/ persyaratan bagi calon pemilih. Dalam konteks kependudukan, mobilitas penduduk merupakan suatu hal yang tidak bisa dicegah atau dibatasi, sementara dengan padatnya agenda penyelenggaraan Pilkada langsung di daerah-daerah yang saling berdekatan, mutasi pemilih antar-wilayah mungkin terjadi. Bahkan yang dikhawatirkan, tidak tertutup kemungkinan ada upaya sistematis berupa mobilisasi calon pemilih demi kepentingan pasangan calon tertentu jika kriterianya tidak jelas. Sekalipun ada klausul bahwa calon pemilih harus memiliki KTP daerah yang bersangkutan, tetapi sudah menjadi rahasia umum, seseorang bisa memiliki dua, bahkan lebih, sehingga duplikasi calon pemilih perlu diantisipasi melalui validasi pendataan penduduk secara aktual.

Ketujuh, dalam hal substansi, pelaksanaan Pilkada langsung juga masih rentan dengan potensi berkembangnya praktik-praktik nondemokratis, antara lain melalui celah proses pengajuan calon yang masih didominasi oleh Parpol, sehingga cenderung mempersempit munculnya calon perorangan.

Kedelapan, pemilihan kepala daerah secara langsung sebagai suatu proses politik, tidak dapat dilepaskan dari konteks sosial-politik-budaya yang melingkupinya. Pascareformasi politik, memang telah terjadi pergeseran fokus kekuasaan yang cukup signifikan, sehingga muncul banyak aktor politik baru, khususnya di level lokal. Namun, munculnya berbagai kekuatan politik baru ini tidak diimbangi oleh pelembagaan nilai-nilai demokrasi, sehingga seringkali proses politik yang berlangsung tetap diwarnai nuansa primordialisme, bahkan premanisme.

Kesembilan, eskalasi politik dan konflik mencapai puncaknya menjelang pelaksanaan Pilkada, sedangkan antisipasi atas konflik yang berkembang tidak disiapkan matang. Tahap pendaftaran dan penetapan calon kepala daerah diselumuti sejumlah masalah yang bahkan di beberapa daerah disertai aksi kekerasan. Mulai dari aksi penolakan terhadap calon tertentu, intimidasi terhadap KPUD untuk meloloskan pasangan calon, sampai gugatan penggunaan ijazah palsu. Konflik makin menjadi-jadi pasca perhitungan dan penetapan suara di sejumlah daerah. Aksi kekerasan yang melibatkan massa banyak terjadi. Di beberapa daerah massa menduduki kantor KPUD dan menyerang anggota KPUD. Hampir semuanya berakar pada ketidakpuasan atas pelaksanaan.

Kesepu/uh, Pilkada langsung juga menyisakan sengketa hukum. Di Kota Depok, ketidakpuasan calon yang kalah dalam perhitungan suara mengajukan gugatan melalui Pengadilan Tinggi Jawa Barat yang ternyata putusan PT Jawa Barat pun malah mengundang konflik yang lebih besar, sehingga Mahkamah Agung langsung turu tangan. Di Kota Depok ada kesan, sangat kontras antara kecepatan proses putusan PT dengan apa yang akan ditentukan oleh MA. Oleh karena itu, Mendagri sempat menunda tahapan Pilkada depok sampai enam bulan. Hal yang sama terjadi di beberapa daerah, seperti dalam Pilgub Papua yang harus menunggu keputusan MA. Ini suatu langkah yang antisipatif, sebab ada dua data empirik yang aktual yang kini dihadapi oleh Depdagri. Selain Depok, Papua dan masalah di daerah lainnya yang harpir sama, adanya dua putusan MA yang memenangkan perkara kasasi yaitu di Provinsi Lampung dan Kabupaten Bekasi oleh lawan politik kedua kepala daerah. Padahal, Gubernur Lampung dan Bupati Bekasi sudah resmi dilantik.

Dalam konteks Teori Demokrasi, kendati sejak 2005-2013 masih terus menyisakan masalah, tetapi secara umum, pelaksanaan Pilkada Langsung telah menunjukkan penguatan indeks pelaksanaan demokrasi di Indonesia. Dahl (1998:67) menyodorkan enam kriteria bagi sebuah negara, sehingga dapat disebut sebagai negara demokrasi, yakni, para pejabatnya dipilih oleh rakyat, dilakukan Pemilu yang bebas, adil, dan berkesinambungan, pemberian kebebasan berekspresi bagi seluruh rakyat, akses informasi yang terbuka luas, kebebasan berasosiasi/ 
Tabel 1

Model Akar Permasalahan Pilkada Langsung

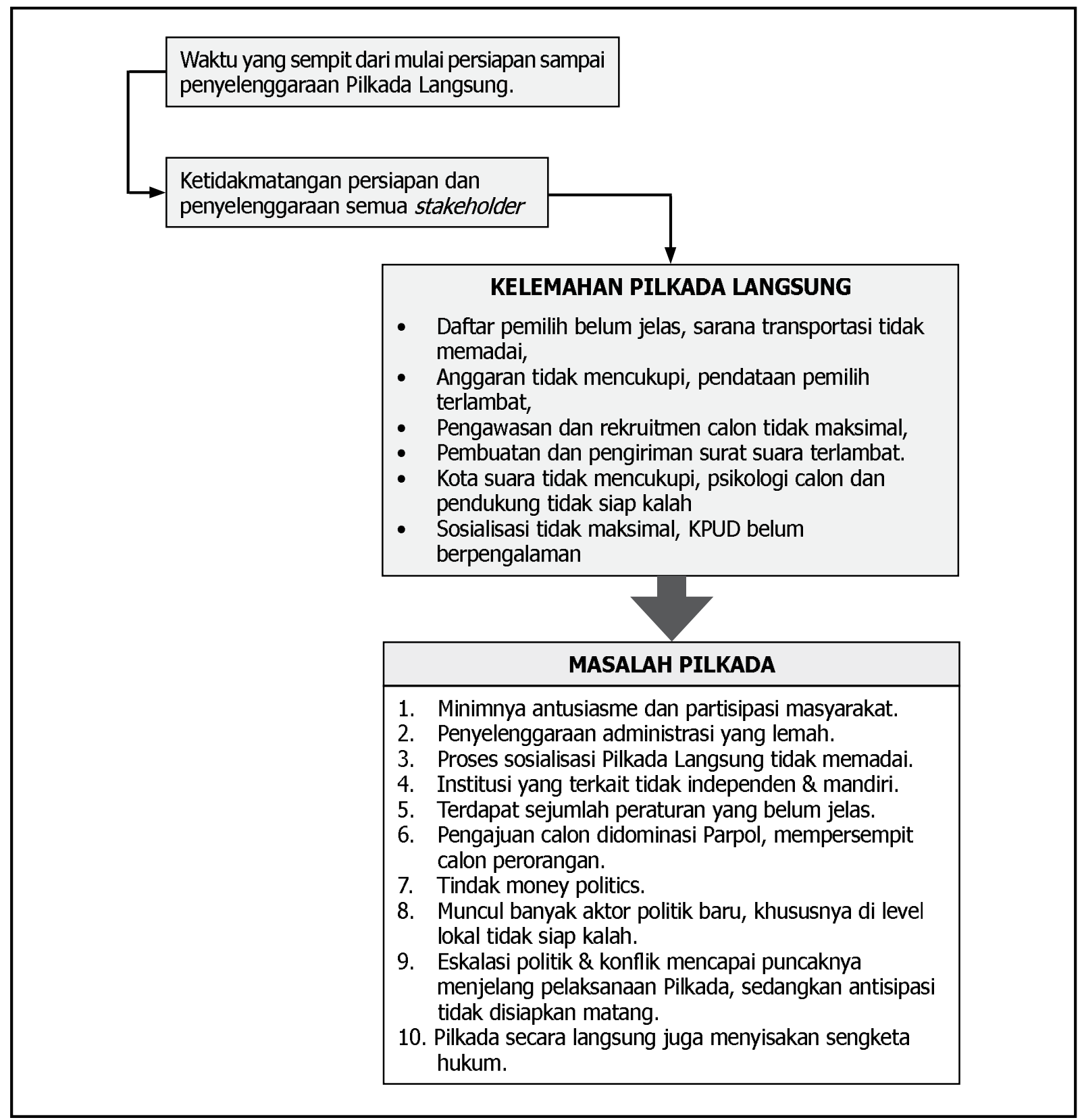

berkumpul, dan kewarganegaraan yang inklusif. Namun, muncul masalah-masalah yang menyertai pelaksanaan Pilkada Langsung menempatkan Indonesia sebagai negara yang dapat diasumsikan baru melaksanakan demokrasi prosedural, di antara empat tingkat demokrasi, yakni, demokrasi prosedural, demokrasi agregatif, demokrasi deliberatif, dan demokrasi partisipatoris.

Demokrasi prosedural adalah persaingan partai politik dan/atau para calon pemimpin politik meyakinkan rakyat agar memilih mereka menduduki jabatan-jabatan dalam pemerintahan (legislatif atau eksekutif) di pusat atau daerah. Terdapat dua unsur penting dalam demokrasi ini: kontestasi/ persaingan secara adil antarpartai dan/atau calon pemimpin, dan partisipasi warga negara dalam menilai dan memberi keputusan atas persaingan tersebut. Dengan demikian, demokrasi terbatas pada partisipasi warga negara yang berhak memilih dalam menentukan wakil rakyat dan/atau kepala pemerintah melalui pemilihan umum yang langsung, umum, bebas, rahasia, jujur dan adil, serta akuntabel. Demokrasi cenderung dipahami sebagai hak partai politik atau calon yang menang Pemilu untuk memerintah alias membuat dan melaksanakan UU dan kebijakan publik lainnya. Inilah yang disebut demokrasi minimal atau prosedural (Schumpeter, 1947: 129). 


\section{Simpulan dan Saran}

Berdasarkan uraian pada bab-bab sebelumnya tentang pelaksanaan Pemilihan Kepala Daerah secara Langsung dan berbagai permasalahan yang muncul di lokasi kajian, dapat diambil kesimpulan sebagai berikut.

Secara umum, dalam konteks substansial pelaksanaan Pilkada Langsung di Indonesia dapat mencapai tujuan akhir, yakni terpilihnya kepala daerah melalui prosesi demokrasi rakyat daerah secara langsung. Namun, tercapainya tujuan akhir Pilkada Langsung di Indonesia bukan jaminan terpilihnya putra bangsa/daerah terbaik, tidak dapat dimaknai telah sempurnanya semua aturan tentang pelaksanaan pemilihan kepala daerah, dan bukan berarti tanpa masalah.

Masalah utama yang melahirkan masalahmasalah lainnya dalam Pilkada Langsung di Indonesia adalah ketidakmatangan rencana yang dilahirkan dari kebijakan umum Pemerintah dalam bentuk "aturan main" pelaksanaan dan kecukupan waktu untuk mengimplementasikan "aturan main" tersebut.

Kecacatan aturan main dan ketidakcukupan waktu implementasi telah melahirkan sederat kelemahan pelaksanaan Pilkada Langsung. Kelemahan yang dimaksud adalah: (a) Daftar Pemilih Belum Jelas; (b) Sarana \& Prasarana, termasuk di dalamnya ketersediaan anggaran tidak memadai; (c) Pengawasan dan rekruitmen calon tidak maksimal; (d) Pembuatan dan pengiriman surat suara terlambat; (e) Kotak suara tidak mencukupi; (f) Psikologi calon dan pendukung tidak siap kalah; (g) Sosialisasi tidak maksimal; dan (h) KPUD belum berpengalaman.

Kelemahan-kelemahan pelaksanaan Pilkada Langsung di Indonesia tersebut telah mendorong lahirnya Pilkada Langsung yang bermasalah. Masalah yang di maksud adalah: (a) Minimnya antusiasme dan partisipasi rakyat; (b) Penyelenggaraan administrasi yang lemah; (c) Proses sosialisasi Pilkada langsung tidak memadai; (d) Institusi yang terkait tidak independen \& mandiri; (e) Terdapat sejumlah peraturan yang belum jelas; ( $f$ ) Pengajuan calon didominasi Parpol, mempersempit calon perorangan; (g) Terjadi tindak money politics; (h) Muncul banyak aktor politik baru, khususnya di level lokal tidak siap kalah; (i) Eskalasi politik \& konflik mencapai puncaknya menjelang pelaksanaan Pilkada, sedangkan antisipasi tidak disiapkan matang; (j) Pilkada secara langsung juga menyisakan sengketa hukum.

Berdasarkan beberapa kesimpulan tersebut, peneliti merekomendasikan beberapa hal sebagai berikut.

Pelaksanaan Pilkada Langsung masih perlu mendapatkan perhatian besar dari seluruh elemen masyarakat guna dilakukan berbagai pembenahan, sehingga hasil akhir yang dicapai dapat memenuhi harapan seluruh rakyat Indonesia yang idealis.

Memperhatikan kehendak rakyat daerah (bottom up) sebagai bagian aspirasi utama dalam membuat "aturan main" pelaksanaan Pilkada Langsung lebih penting ketimbang, kehendakkehendak parsial elite politik pemerintah pusat (top down). Kehendak rakyat lokal yang paling berharga bukan kehendak elite politik (Parpol) daerah, tetapi kehendak grassroots yang berada di daerah.

Proses Pilkada Langsung mulai tahapan perencanaan (planning), pelaksanaan (implementing), dan penilaian (evaluating) harus lebih mengakomodasi kondisi dan situasi setiap daerah yang akan melaksanakan, terutama berkait dengan karakteristik geografis dan kultur masyarakat lokal.

Merevisi UU No. 32 Tahun 2004 tentang Pemerintahan Daerah dan Peraturan Pemerintah No. 6 Tahun 2005 tentang Pelaksanaan Pilkada Secara Langsung untuk lebih berpihak kepada grassroots, ketimbang pada Parpol.

Menyosialisasikan dan mempublikasikan peraturan pelaksanaan Pilkada Langsung kepada seluruh rakyat secara menyeluruh dan merata. Kemudian memandirikan dan mengindependenkan lembaga penyelenggara dan pengawasan Pilkada langsung.

\section{Daftar Pustaka}

Astawa, I Gde Pantja. (2013). "Seminar Keterbukaan Unformasi dalam Pilgub Jabar 2013" di Hotel Katulistiwa Jatinangor, 12 Desember 2013.

Djohermansyah. (2014). Makalah tertulis yang dibawakan Kepala Subdirektorat Otonomi Daerah Kementerian Dalam Negeri Andi Bataralifu dalam "Konferensi Nasional Hukum Tata Negara" di Sawahlunto, Jumat (30/5/2014)

Iskandar, Rusli Kustiaman. (2003). Menuju Demokratisasi Pemilihan Presiden. Jurnal MIMBAR Sosial dan Pembangunan Vol. 19, No. 1 Tahun 2003 Penerbit P2U LPPM Unisba

Hikmat, Mahi M. (2010). Komunikasi Politik: Teori dan Praktik. Bandung: Simbiosa Rekatama Media

Hikmat, Mahi M. (2010). Komunikasi Politik dalam Pemilihan Gubernur Jawa Barat Tahun 2008. Bandung: Disertasi Pascasarjana Universitas Padjadjaran.

Hikmat, Mahi M. (2005). Perilaku Politik Anggota DPRD Jawa Barat dalam Pemilihan Gubernur Jawa Barat Tahun 2003. Bandung: Tesis Pascasarjana Universitas Padjadjaran.

https://www.facebook.com/PRFMNewsChannel http://www.rumahpemilu.org/in/read/1965/Konflikdi-Banyak-Pilkada.

http://www.investor.co.id/home/tiga-meninggalkonflik-pilkada-di-sumba-daya-barat/67917

http://pilkadaponorogo.com. 
Media Indonesia, 30 Maret 2005.

Nurlimah, Nila. "Konflik Politik Capres SBY, JK, Megawati di Media Massa". Jurnal MIMBAR Sosial dan Pembangunan, Vol. XXVII, No. 1 (Juni 2011) Penerbit P2U LPPM Unisba.

Peraturan Pemerintah No. 6 tahun 2005 tentang Pemilihan Kepala Daerah.

Prawira, Indra dalam "Bincang-Bincang Pilkada" pada PR FM, 8 Agustus 2013.

Rasyid, Ryaas. (2013). Ceramah umum anggota Dewan Pertimbangan Presiden RI, Kamis 2 Mei 2013 di Lembaga Administrasi Negara Makasar

Robert Dahl. (1989). Democracy and Its Critic. New Haven, NJ: Yale University Press.

Jean JacQues Rousseau, (1986), Kontrak Sosial
Terjemahan Sumarjo, Erlangga, Jakarta Joseph A. Schumpeter. (1947)., Capitalism, Socialism, and Democracy. 2d ed. New York: Harper

Susilo, I Basis. (1998). "Teori Kontrak Sosial dari Hobbes, Locke, dan Rouseau" dalam Jurnal Masyarakat, Kebudayaan, dan Politik. Surabaya: Fisip Unair.

Surbakti, Ramlan. (2008). Perekayasaan Sistem Pemilu. Jakarta: Kemitraan bagi Pembaharuan Tata Pemerintahan di Indonesia.

Undang-Undang No. 22 Tahun 1999 tentang PokokPokok Pemerintah Daerah.

Undang-Undang No. 32 Tahun 2004 tentang Pemerintahan Daerah. 